BMJ Surgery, Interventions, $\&$ Health Technologies

\section{Innovation in surgery}

To cite: McCulloch $P$. Innovation in surgery. BMJ Surg Interv Health Technologies 2019;1:e000021. doi:10.1136/ bmjsit-2019-000021

Received 05 August 2019 Accepted 05 August 2019

\section{SLinked}

- http://dx.doi.org/10.1136/ bmjsit-2019-000002

- http://dx.doi.org/10.1136/ bmjsit-2019-000015

\section{Check for updates}

(C) Author(s) (or their employer(s)) 2019. Re-use permitted under CC BY-NC. No commercial re-use. See rights and permissions. Published by BMJ.

Nuffield Department of Surgical Science, University of Oxford, Oxford, UK

Correspondence to Professor Peter McCulloch; peter.mcculloch@nds.ox.ac.uk
Innovation in surgery, as in any other discipline, is by definition a challenge to the status quo. Such challenges will inevitably elicit critical responses from those who believe in the status quo, and especially from those who have devoted time and energy to creating and shaping it. As Machiavelli ${ }^{1}$ drily pointed out, initiating change is a risky business, since those who are most likely to oppose it are those who have flourished under the current regime. Where change is incremental, or aligned with current accepted wisdom, it is not likely to raise controversy-but the converse also applies.

The paper "The precision prostatectomy: An IDEAL Stage 0 and 1/2a study" by Sood et $a l^{2}$ falls into the category of controversial innovation. Coming from the group of the originator of robotic prostatectomy, the new operation described challenges current doctrine, and has therefore raised concerns among experts in the field. Surgical oncologists in general adhere strongly to the principle of complete excision of all loco-regional cancer tissue, and indeed their raison d'etre as a professional group is the proposition that they can achieve better local control than any other treatment modality. The proposition that complete local extirpation also leads to better long-term survival is much more strongly supported by empirical evidence in some types of cancer (eg, gastric or colorectal) than others. Early prostate cancer, like breast cancer, is an example of a disease where the evidence has shown that persistence of local disease does not necessarily reduce the chances of long-term survival. ${ }^{3}$ The proposition behind the new procedure proposed by Sood $e t$ al is based on this understanding and on the recognition that patient values often encompass more than simply survival. In a context where death from the disease is unlikely, and the survival benefit of complete local removal is unproven, they suggest that a trade-off between an unquantifiable (and possibly zero) survival benefit from complete clearance and improvement in functional outcomes may be reasonable and in line with many patients' wishes. This does not accord with the mainstream of current expert opinion in their professional group, as the accompanying perspective by $\mathrm{Neal}^{4}$ makes clear. In these circumstances, responsible innovation requires great care in minimizing risk to patients, complete transparency (both in reporting to peers and in explaining the situation to patients during informed consent), and the collection of the data most likely to assist us in reaching conclusions quickly and appropriately.

The IDEAL Recommendations, which Sood has followed closely, are designed to support these objectives. Of particular note are the full disclosure to the patient about the status of the operation and its current state of development and the reflection on difficulties and how the procedure might be modified in the future. A debate conducted on the basis of the fullest possible understanding of the procedure and its outcomes, including, in early innovation, explanation of any changes or evolution in thinking or practice, is more likely to be productive than one in which not all the information is available to all parties. Whatever your view of the merits of the precision prostatectomy, its publication in the IDEAL format is a commendable effort to ensure its evaluation proceeds according to ethical and scientific principles. BMJ Surgery, Interventions, E Health Technologies therefore welcomes the article and looks forward to the ensuing stimulating debate.

Funding The authors have not declared a specific grant for this research from any funding agency in the public, commercial or not-for-profit sectors.

Competing interests None declared.

Patient consent for publication Not required.

Provenance and peer review Commissioned; internally peer reviewed.

Open access This is an open access article distributed in accordance with the Creative Commons Attribution Non Commercial (CC BY-NC 4.0) license, which permits others to distribute, remix, adapt, build upon this work non-commercially, and license their derivative works on different terms, provided the original work is properly cited, appropriate credit is given, any changes made indicated, and the use is non-commercial. See: http://creativecommons.org/licenses/by-nc/4.0/. 


\section{REFERENCES}

1. Machiavelli N. The Prince. Translated by George Bull, ISBN 978-0-14044915-0. London: Penguin, 1961.

2. Sood Jeong W, Kanika T, Abdollah F, et al. The precision prostatectomy: an IDEAL stage 0 and $1 / 2 A$ study.
3. Hamdy FC, Donovan JL, Lane JA, et al. 10-Year outcomes after monitoring, surgery, or radiotherapy for localized prostate cancer. $N$ Engl J Med 2016;375:1415-24.

4. Neal D. Precision prostatectomy: reconciling functional and oncological outcomes?. 